0000000000000000000

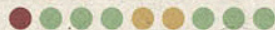

-

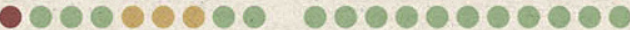

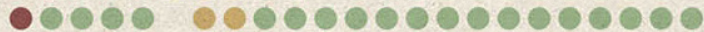

O

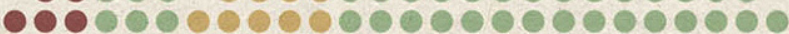

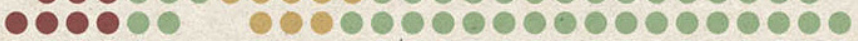
00000

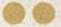
\%

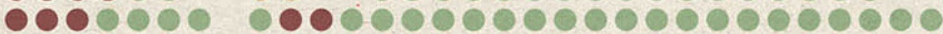

10

100

0000000000000000000

000

1000

0000000000000000

00000000000000000

10

10

10000000000000000

80

100

100

00000

0000000000000000000000

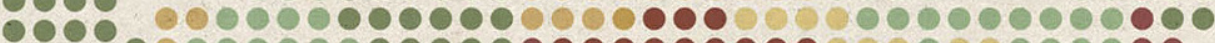
00000000000000000000000000000000000

- 00000000000000000000000000000000000

000000000000000000000000000000000000000

0000000000000000000000000000000000000

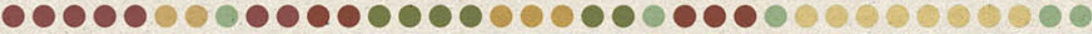

000000000000000000000000000000000000

10.0000000000 .00000000000000000000000000

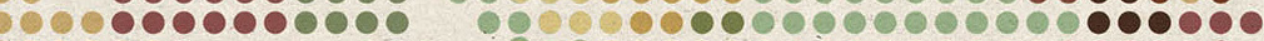

00000

10000

1000

100

10

(6)

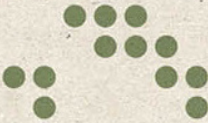

100000000000000000000000

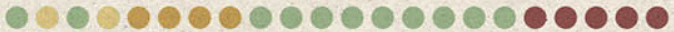

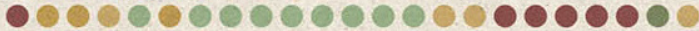

- 00 000000000000000000000

0000000000000000000000000

00000000.0000000000000000

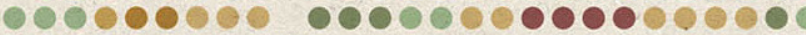

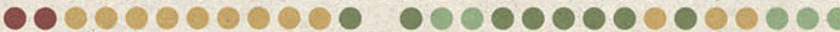

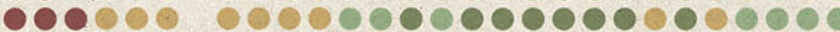

OPOPO

OOPOOPO

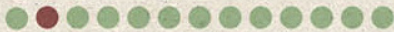

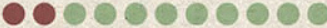

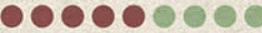

ropo o. 000000000000000000

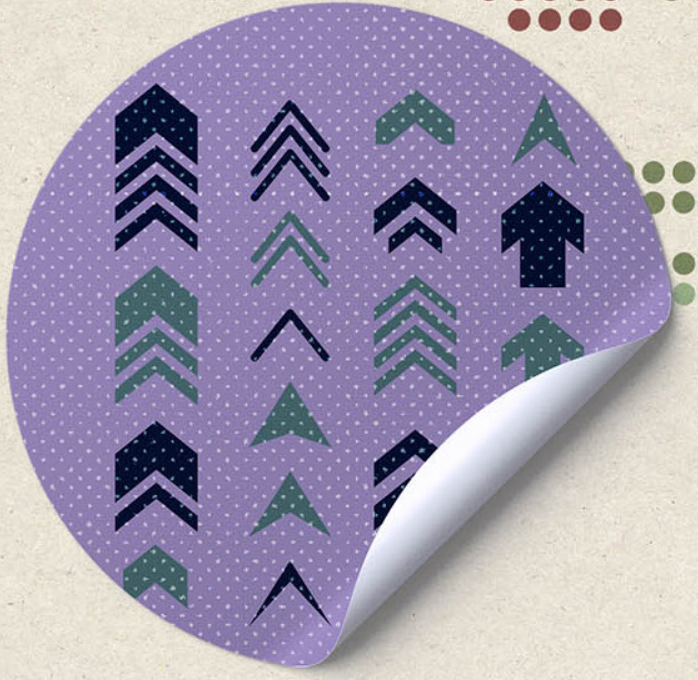

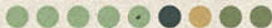

00000000

00000000 0000000

10000000

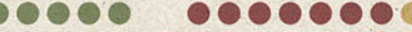
00000000000 100 So 0

Pe

OPe

○ᄋ

- 19

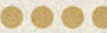

000

O 


\title{
A estratégia regional fronteiriça frente às diretrizes do Programa de Promoção do Desenvolvimento da Faixa de Fronteira
}

\author{
The border region strategy in the face \\ of the guidelines of the PDFF \\ (a governmental program dedicated to \\ developing the border area of Brazil)
}

\author{
Dianine Censon* | Elaine da Silveira Leite** \\ http://dx.doi.org/10.51861/ded.dmvu.2.017 \\ Recebido em 24 de junho de 2020. Aceito em 13 de maio de 2021.
}

\section{Resumo}

Em 2009 é lançado o Programa de Promoção do Desenvolvimento da Faixa de Fronteira, versando sobre a organização e o aperfeiçoamento das políticas públicas como forma de criação de oportunidades para a integração da faixa de fronteira ao cenário de desenvolvimento nacional. Pensando na realidade da metade sul do Rio Grande do Sul, o objetivo deste trabalho foi compreender de que forma as diretrizes pró-desenvolvimento do Governo Federal configuraram o debate sobre desenvolvimento regional no poder público da cidade de Jaguarão/RS. Para isso, em 2015 e 2016 foram realizadas entrevistas semiestruturadas com representantes do poder público municipal. As entrevistas abordaram o período em que aqueles representantes encontravam-se atuando na gestão pública local, 2009-2016. Foi possível elencar categorias de desenvolvimento presentes no poder público de Jaguarão, observando a legitimação de uma doxa local que se relaciona, subjetivamente, às doxas de desenvolvimento em curso em outras localidades do Brasil.

Palavras-Chave: Fronteiras; Desenvolvimento Regional; Políticas Públicas; Políticas de Integração; Gestão Pública Municipal.

\begin{abstract}
In 2009, the Brazilian Federal Government launched a governmental program dedicated to developing the country's border area. The program talks about the organization and improvement of public policies to create opportunities to integrate the border area into the national development scenario. This work aimed to comprehend how the guidelines pro-development by Federal Government configure the debate about regional development in the public power of the city of Jaguarão/RS. Between 2015-2016 semistructured interviews were conducted with local public power representatives. The interviews asked about 20092016 when those representatives were working in the local public management. It was possible to find development categories expressed by the public power of Jaguarão, guiding to the legitimation of a local doxa. This doxa is subjectivity related to other development doxas in different places of Brazil.
\end{abstract}

Keywords: Border Areas; Regional Development; Public Policies; Integration Policies; Local Public Management.

\footnotetext{
* Doutoranda em Sociologia pela Universidade Federal do Rio Grande do Sul. Professora temporária do curso de Bacharelado em Turismo da Universidade Estadual do Centro-Oeste. Universidade Estadual do Centro-Oeste, Departamento de Turismo. Rua Professora Maria Rosa Zanon de Almeida, Riozinho, Irati, PR - Brasil, 84505677. ORCID: https://orcid.org/0000-0001-7071-850X.E-mail: dianinecenson@gmail.com

** Professora Adjunta de Sociologia e professora do Programa de Pós-Graduação em Sociologia da Universidade Federal de Pelotas. Doutora em Sociologia pela Universidade Federal de São Carlos. Coordenadora do GENS (Grupo de Estudos em Novas Sociologias - Econômica, Finanças e Família). Universidade Federal de Pelotas, Departamento de Sociologia e Política. Rua Cel. Alberto Rosa, Centro, Pelotas, RS - Brasil, 96010770.

ORCID: https://orcid.org/0000-0003-1402-3839. E-mail: esleite20@gmail.com
} 


\section{INTRODUÇÃO}

Em 2007 foi lançada, pelo Ministério da Integração Regional, a Política Nacional de Desenvolvimento Regional (PNDR), com o objetivo de compreender e sistematizar questóes regionais brasileiras relacionadas a problemas de falta de integração físico-estrutural, econômica e política (BRASIL, 2007). Passando por atualizaçóes em 2010 e 2019, a política passou a utilizar-se dos termos coordenação, integração, articulação e convergência para denotar sua mais nova e pragmática organização, destacando a necessidade de estímulo aos sistemas e arranjos produtivos locais como forma de inserção e organização social, bem como dinamização da economia (BRASIL, 2010a; 2019).

Regióes historicamente esquecidas e desfavorecidas fazem parte dos objetivos da PNDR, a fim de promover inclusão social, produtividade, sustentabilidade ambiental e competitividade econômica (Brasil, 2007). Alguns dos argumentos da Política versam sobre a 'injustiça' de se nascer ou viver em um local historicamente desfavorecido em termos sociais, econômicos, bem como distantes dos centros administrativos e financeiros do país. Isso, de acordo com o descrito pela PNDR, acarreta a exclusão dessas regióes frente ao desenvolvimento brasileiro, gerando desvantagem competitiva frente às localidades melhor geograficamente inseridas no cenário nacional (BRASIL, 2007; 2012a; 2019). Pensando nessa urgência em integrar regióes com essas características de esquecimento e exclusão, em 2009 toma forma o Programa de Promoção do Desenvolvimento da Faixa de Fronteira (PDFF), política que embasou este trabalho.

O Programa traz como objetivos ações que versam sobre a organização e o aperfeiçoamento das políticas públicas como forma de criação de oportunidades para a integração da faixa de fronteira ao cenário de desenvolvimento nacional (BRASIL, 2009a; 2010b; 2011). Ao buscar integrar essas regióes, as justificativas do PDFF discorrem sobre a atenção às identidades culturais e econômicas fronteiriças, como forma de afirmação dos princípios básicos de i) autonomia, ou descentralização; ii) cooperação vertical e horizontal; iii) coordenação e; iv) equidade, ou solidariedade (coesão) regional que permeiam o sistema federativo brasileiro (BRASIL, 2012a).

Dentro do PDFF houve a sub-regionalização da faixa de fronteira, a fim de se pensar separadamente cada realidade. Uma dessas sub-regióes é o Arco Sul, que abrange as fronteiras internacionais dos estados do Paraná, Santa Catarina e Rio Grande do Sul, cada qual também inserido em importantes especificidades inter-regionais (BRASIL, 2009a). No Rio Grande do Sul e, especificamente, na sub-região referente à metade sul do estado, campo desta pesquisa, as características apontadas pela Cartilha da Faixa de Fron- 
teira dizem respeito ao alto grau de urbanização dos municípios, pela grande extensão destes, e a produção especializada em bovinocultura, ovinocultura e rizicultura, voltada tanto para o abastecimento do mercado nacional e internacional (BRASIL, 2009a). Ainda assim, por uma série de acontecimentos históricos, a região é compreendida na Cartilha como pouco integrada ao cenário nacional, necessitando de novas atençôes e oportunidades para o seu desenvolvimento.

Em sintonia com isso começam a tomar forma, em 2009, movimentaçóes em torno do Projeto de Lei no 6.316, tratando sobre a abertura de free shops ${ }^{1}$ no lado brasileiro das fronteiras internacionais (BRASIL, 2009b). Em 2012 é sancionada a Lei no 12.723 , autorizando a instalação do comércio de free shops nas cidades brasileiras de fronteira (BRASIL, 2012b). Os esforços políticos para a abertura desses free shops no lado brasileiro das fronteiras com o Uruguai, Argentina, Paraguai, Bolívia, Peru, Colômbia, Venezuela, Guiana, Suriname e Guiana Francesa motivaram o interesse dessa pesquisa pela cidade de Jaguarão. A cidade foi palco de assembleias, em especial nos anos de 2014 e 2015, e reunióes representativas das 10 cidades do Rio Grande do Sul (a saber, Santana do Livramento, Chuí, Jaguarão, Porto Xavier, Aceguá, Barra do Quaraí, Itaqui, Quaraí, São Borja e Uruguaiana) contempladas pela possibilidade dessa nova atividade. Além disso, o prefeito da cidade (gestóes 2009-2012 e 2013-2016) foi escolhido como coordenador do Fórum de Prefeitos das Cidades Gêmeas do Rio Grande do Sul (PREFEITURA MUNICIPAL DE JAGUARÃO, 2015).

Inicia-se então uma reflexão pautada por esses desdobramentos, pelas inquietaçóes a respeito da PNDR e do PDFF, e pela análise prévia das cidades de fronteira do Rio Grande do Sul e das suas características sociais, seus empreendimentos, investimentos, e açôes políticas (CENSON, 2019). Com isso, o objetivo desta pesquisa foi compreender de que forma as diretrizes pró-desenvolvimento do Governo Federal configuraram o debate sobre desenvolvimento regional no poder público da cidade de Jaguarão/RS. Posto que este texto faz parte de uma pesquisa mais ampla, aqui somente foram destacadas as entrevistas com os agentes do poder público local ${ }^{2}$. Isso de forma a apresentar quais temáticas e argumentos emergiam destes agentes como estratégias de desenvolvimento, em referência ao período em que estes encontravam-se atuando na gestão pública da cidade, a saber, 2009-2016, buscando compreender a doxa (Cf. Bourdieu, 1977) do desenvolvimento local, que se constitui na crença em afugentar os fantasmas da estagnação e esperançar o progresso. 


\section{PROCEDIMENTOS METODOLÓGICOS}

De forma a compreender o contexto e o processo de criação do PDFF e as suas diretrizes, inicialmente foi feita a análise documental não-sistemática (LAVILLE \& DIONE, 1999), com materiais oficiais e publicações das instâncias públicas governamentais federais, estaduais e municipais (LIAKOPOULOS, 2002).

Com base nos documentos analisados, foi possível reconhecer o secretário de Planejamento e Urbanismo como representante do poder público local que, naquele momento, mais envolvia-se com o processo de instalação dos free shops. Uma entrevista exploratória semiestruturada (TRIVIÑOS, 1987) foi realizada em setembro de 2015 . O entrevistado mencionou outros representantes do poder público local que se vinculavam com a temática abordada, o que acarretou novas análises documentais e reajuste das temáticas a serem abordadas. A partir da ampliação dos questionamentos e da análise, novas entrevistas foram realizadas em março de 2016. Finalmente em setembro de 2016 aconteceram as últimas entrevistas da pesquisa, sempre a partir de novas indicações dos entrevistados.

Dessa forma, o campo foi mapeado situando os agentes (Cf. Bourdieu, 1989) que tinham mais envolvimento com o processo de instalação dos free shops e, posteriormente, com novos agentes mencionados durante as entrevistas. Tem-se, em uma hierarquia que considera o papel do agente neste processo, o prefeito da cidade (agente 1 ), o vice-prefeito e candidato a prefeito (agente 2), o secretário de Planejamento e Urbanismo (agente 3), o ex-secretário de Desenvolvimento Econômico e Desenvolvimento Social e candidato a vereador (agente 4), a secretária de Cultura e Turismo (agente 5), o produtor cultural (agente 6), o historiador (agente 7) e a turismóloga (agente 8) da Secretaria de Cultura e Turismo.

De forma conjunta, o foco das entrevistas girava em torno da 1) sanção da lei no $12.723 ; 2$ ) o envolvimento da cidade com o Programa de Aceleração ao Crescimento - PAC (PREFEITURA MUNICIPAL DE JAGUARÃO, 2013); 3) o papel da Universidade Federal do Pampa para a cidade, a partir de 2006, e as negociações com a abertura de um Instituto Federal Sul-rio-grandense - IFSUL na cidade; 4) as obras de infraestrutura em curso; 5) a construção da segunda ponte entre Jaguarão e Rio Branco, aprovada em 2009 e licitada em 2014; 6) o Carnaval; e 7) as eleiçôes municipais.

A partir das entrevistas foi utilizada a técnica de análise interpretativa (TRIVIÑOS, 1987), procurando relacionar momentos e excertos das respostas dos atores entrevistados com a teoria referente à temática. Também foi de suma importância apoiar-se em Vainer (2000), ao tratar de uma estratégia discursiva do Planejamento Estratégico Urbano, na qual discute-se ana- 
logias constitutivas às novas posturas sendo desempenhadas pelas cidades, a saber: 1) a cidade-produto, na qual as suas orientaçôes visam sua comercialização pela lógica do mercado; 2) a cidade-empresa, em que ao invés de cidade administrada ela passa a ser empresarizada, isto é, tomando a ideia de empresa como um modelo universalmente generalizável como um símbolo de progresso, de eficiência, de modernização; e 3) a cidade-pátria, que passa a ser pautada quando se tem a necessidade de ser sempre pensada como um espaço-sujeito coeso, no qual todos os atores públicos e privados, bem como a sociedade civil, estejam em sintonia.

\section{DO ESTADO A FRONTEIRA: APROXIMAÇÕES E REFLEXÕES TEÓRICAS}

A formulação das políticas públicas pelo Estado brasileiro, considerando-se a extensão do território, traz consigo a responsabilidade de um Estado que contemple as particularidades de localidades tão diversas. Parece haver, no entanto, um conjunto de normas e regras naturalizadas socialmente que orientam a compreensão das políticas e das medidas governamentais como processos padronizados e assertivos.

Parte dessa naturalização pode ser observada na emergência ao chamado desenvolvimento, que figura no pensamento das naçóes como problemática central. No Brasil, principalmente a partir da década de 1950, permeadas pela lógica da dependência, as preocupaçóes passaram a girar em torno do desenvolvimento social, econômico e cultural (CARDOSO, 1978). A princípio, o grande incentivo à industrialização, unido à urbanização, foram as engrenagens de um sistema que primava pela lógica da libertação do Estado brasileiro das suas dependências internacionais, inflando a necessidade de desenvolvimento do capitalismo brasileiro (CARDOSO, 1978). A noção de desenvolvimento, assim, remete a crescimento, progresso e adiantamento, mas passa a ter sua interpretação difundida sem a explicação de qual crescimento (ou progresso, ou adiantamento) se refere.

O que pode ser observado, desde a década de 1960, é uma exacerbação do desenvolvimento econômico frente às outras esferas (seja social, seja cultural, seja humana etc.). Para Leme (2015), esse processo de discussão do desenvolvimento brasileiro pode ser entendido, também, como um debate sobre quais estratégias devem ser adotadas para atingir o desenvolvimento, passando, necessariamente, pela questão das estratégias econômicas (LEME, 2015).

Frente às estratégias, cabe refletir acerca do clima de prosperidade que parece permear o sentido das orientaçóes pró-desenvolvimento do Estado 
(IANNI, 1977) como ferramenta da manutenção dos atores no jogo público-administrativo. No entanto, de tempos em tempos, o aparente sucesso dos esforços ao desenvolvimento propagados pelo governo e pela mídia é questionado, uma vez que cresce a nação, classes sociais específicas enriquecem-se, setores inovam-se, mas o sentimento de abismo de desigualdade social e o esquecimento de alguns espaços da sociedade brasileira continua a figurar (IANNI, 1977). Há limites para que uma estratégia de desenvolvimento nacional se torne viável no Brasil, e esses limites envolvem não somente contextos políticos específicos, mas também questões estruturais na formação do Estado brasileiro, pressões internacionais etc. (LOPES, CONCEIÇÃ̃O \& PEREIRA, 2019).

Assim é possível observar que as estratégias e trajetórias que compõem a elaboração de planos, projetos e políticas, bem como as orientaçôes nacionais, são continuamente redefinidas (BOSCHI \& GAITÁN, 2009), moldando-se e adaptando-se às demandas e expectativas atuais e às emergências nacionais diversas. Alguns planos de desenvolvimento, assim, procuram dar conta de diminuir estes abismos e construir uma sociedade mais igualitária, seja pensando na educação, na saúde, na economia, na cultura etc. Peca-se, no entanto, na atenção às necessidades e particularidades de cada localidade, não observando "a existência de comunidades discursivas distintas, de visões de mundo e interesses conflitantes, e as diferenças de recursos dos atores sociais, inclusive comunicacionais" (COSTA, 2008, p. 106). Também se critica uma "utopia do planejamento" a nível local e regional, marcada por boas intençốes que acabam, na realidade, beneficiando os mesmos núcleos de poder já em destaque frente à economia e a política nacional (BRANDÃO, 2011).

Essa "nova forma" de compreender os espaços vem dando lugar a uma discussão crítica dos conceitos de região, território, cidade etc., que se tem de forma teórica e, por outro lado, como se vêm pautando na forma prática. Atualmente, os espaços são tratados como objetos e açôes, como lócus de poder representativos da própria imagem e ação do homem que nele habita, como formas de se relacionar às interações sociais a que sofre, funcionando como construçốes sociais e instrumentos de poder (SANTOS, 2005; SENNETT, 2003; SILVA, 2013). Dessa maneira, a inserção da preocupação a respeito das regiốes historicamente esquecidas da PNDR pode ser compreendida como uma tentativa de transformar esses espaços em atores políticos, articulando e sendo articulados pelas orientaçóes do Estado, apoiados com naturalidade pela sociedade civil e, principalmente, recebendo forte participação da iniciativa privada (CASTELLS \& BORJA, 1996). Pode-se questionar, ainda, qual a motivação de tais programas e a quais grupos econômicos, políticos, sociais, privados (ou não), se intenciona beneficiar - seja em aspectos de cres- 
cimento econômico, seja em prol de um reconhecimento social, seja em vias da promoção de um ideal, entre as mais diversas motivações que se pode ou não imaginar na dada situação.

Os próprios materiais oficiais veiculados pelo Estado sinalizam este questionamento. Ainda descrevendo a necessidade de uma PNDR, fala-se em um histórico de garantia do território brasileiro acordado entre governos centrais e elites regionais, situação que, por um lado, auxiliou na manutenção de uma base territorial sólida, mas, por outro, deu a tais elites "a prerrogativa ou o poder de configurar áreas sob sua influência” (BRASIL, 2010b, p. 7-8). A fase II da PNDR, considerando o que foi erroneamente feito no "passado", propóe-se a pensar em um Brasil menos desigual, estabelecendo programas como o PDFF.

Pensando, portanto, sobre realidades locais e o PDFF, nota-se que apesar de o discurso de diferenciação que os espaços fronteiriços vêm tendo frente aos demais espaços, não há a preocupação direta em considerar essas diferenças no planejamento administrativo. Há, por outro lado, uma motivação de igualá-los aos espaços não fronteiriços em aspectos econômicos, pró-desenvolvimento, sociais e espaciais. Sobre isso, a Cartilha de Faixa de Fronteira deixa bem claro, no início do documento, que o desafio é "fazer com que os mais diversos segmentos socioeconômicos e culturais do país se integrem ao processo de desenvolvimento nacional e dele usufruam em termos de melhoria da qualidade de vida de seus integrantes” (BRASIL, 2009a, p. 4).

Aqui, cabe maior atenção ao nome do Programa ser, necessariamente, "Promoção do Desenvolvimento da Faixa de Fronteira". A utilização da palavra 'desenvolvimento' pode ser tida como uma marca da doxa (Cf. Bourdieu, 1977) de desenvolvimento dominante no ideal nacional. Pensar em uma doxa dominante é considerar que paira uma ideia inconsciente, de que é socialmente "natural" a procura pelo crescimento desses espaços (BOURDIEU, 1977). O campo da doxa, assim, é um conjunto de pressupostos admitidos como evidentes, aquém de qualquer debate ou discussão, que não precisa ser pensado, que é natural e socialmente aparente (BOURDIEU, 1977; 1983). A ideia de doxa ainda pressupóe certo tradicionalismo, a ideia de "mundo natural” e de garantias, o que se une a um processo de instrumentalização política que contribui para a reprodução do mundo social produzindo uma imediata aderência ao mundo como produto e reprodução de estruturas clássicas em uma forma transformada (BOURDIEU, 1977). Além disso, pode-se pensar na relação entre "ordem objetiva e princípios subjetivos da organização do mundo" (BOURDIEU, 1977, p. 162) que regem tais orientaçôes de integração e desenvolvimento da fronteira.

Se pensar-se além, no espaço político nacional, constituído por uma gama muito maior de relações e disputas (Cf. Bourdieu, 2014), é indissociá- 
vel a ideia de legitimidade que os proponentes dessas alteraçóes em nome da doxa do desenvolvimento têm frente a realidade local. Ao seguir uma política nacional, que vem sendo trabalhada em diversas regióes do Brasil e, de fato, mostrando melhorias, a legitimidade da fala política nos âmbitos locais se mostra verossímil com a realidade, acabando por naturalizá-la. Por isso, configura-se, utilizando-se aqui o conceito de Elias (1999), um debate regional acerca do desenvolvimento de determinados espaços como mais uma tentativa de inseri-los nas atenções dos núcleos do país e, principalmente, no crescimento econômico nacional. Para Elias (1999), os comportamentos individuais, as açôes próprias daquele espaço, devem levar em consideração toda a gama de interdependência na estrutura da sociedade. Assim, pensando nas diretrizes de desenvolvimento do Governo Federal e na forma como cada poder público local lida com suas atribuiçóes, pode-se compreender que neste momento e cenário particular, as administraçóes públicas das áreas fronteiriças terão um comportamento específico, configurado a partir das orientaçôes específicas em curso. Essas configurações parecem relativamente autônomas, mas ao analisá-las no conjunto da ordem pré-determinada pela estrutura, vê-se a impossibilidade de isolá-las na relação para com o todo (ELIAS, 1999). Vitte (2006) discute sobre a dimensão política e quanto às instituições têm papéis decisivos nos debates sobre desenvolvimento, o que leva a refletir sobre tudo que está intrínseco nessas relaçóes, nas lutas e formas de poder que desenham essas linhas, como e por quem elas são orientadas.

Para Dittrich (2012), as fronteiras constituem realidades bastante complexas, uma vez que as suas materialidades são diferentes daquelas concepçóes e representações praticadas em espaços não fronteiriços. Nesses locais, é fácil enganar-se considerando apenas o aspecto geográfico como limitador, desconsiderando que fronteiras civilizacionais, espaciais, culturais, de visões de mundo, de etnias, de história e do humano (DITTRICH, 2012) são aspectos igualmente importantes na configuração das dinâmicas do espaço, da relação dos indivíduos para com ele e das ações desenvolvidas ali. Para Silva e Prado (2014), toda a gama de conceitualização de "fronteira", ainda se encontra de certa forma incompleta, havendo uma necessidade de aprofundar discussões acerca das dinâmicas específicas que envolvem questóes econômicas, migratórias, políticas, sociais e culturais. A ideia de cidade transmutada para uma imagem que pouco ou nada faz referência ao ideal original, a inversão dos valores em busca de uma "salvação" e a reestruturação urbana são, para Teobaldo (2010), formas de tentar inserir-se na economia global, o que se leva a pensar justamente na relação entre as políticas de integração fronteiriça com a definição schumpeteriana de novas combinaçóes (SCHUMPETER, 1988) como receituário para o desenvolvimento que se transformou na doxa (Cf. 
Bourdieu, 1977) da atualidade. Essa doxa (Cf. Bourdieu, 1977), mesmo que considerando especificidades locais, traduz em espaços repletos de diferenças algumas formas de se pensar e se administrar as cidades que parecem promissoras em uma visão um tanto quanto padronizada.

Com isso é possível retomar as analogias constitutivas de Vainer (2000). Como mencionado anteriormente, Vainer discute três formas que vêm sendo desempenhadas pelas cidades, em conjunto ou não, e que acabam por alterar as lógicas urbanas e as interaçôes sociais destas localidades. São elas: a cidade-produto, a cidade-empresa e a cidade-pátria (VAINER 2000).

A primeira delas, a cidade-produto, pressupõe que o espaço urbano deve dispor de algum atrativo que o torne vendível e competitivo. Para esse processo, outros princípios da administração empresarial são retomados, como, por exemplo, a necessidade de uma pesquisa acerca dos compradores visados, o trabalho de marketing do produto urbano (chamado de marketing urbano) (VAINER, 2000). Para o autor, ainda, o interesse de venda da cidade-produto é sempre o mercado externo e, principalmente, um mercado de luxo, levando-se a questionar a preocupação com o mercado interno, ou seja, os próprios locais, e com aqueles sem solvabilidade para adquirir tal "produto" (VAINER, 2000).

Em sintonia com a cidade-produto, Vainer (2000) discorre sobre a coexistência desta com a analogia da cidade-empresa. A transformação da cidade passiva em ativa, em sujeito, precede aos mesmos princípios de transposição da administração empresarial à administração pública. Vainer (2000) ainda relembra o urbanismo modernista e a ideia de uma cidade taylorista, com "racionalidade, funcionalidade, regularidade e produtos estandardizados" (VAINER, 2000, p. 85). Para o autor a produtividade, a competitividade e a subordinação às lógicas do mercado dão forma a essa cidade-empresa, e trazem consigo a necessidade de parcerias público-privadas uma vez que "se o assunto é business, melhor deixá-lo nas mãos de businessmen" (VAINER, 2000, p. 87). Essa nova definição do poder local altera não só questóes administrativas, mas também toda a lógica de interação social e constituição de cidadania onde, tal qual em uma empresa, todos os atores devem empenhar-se nos processos em marcha: sejam eles de produção, de venda, de marketing etc. (VAINER, 2000).

Finalmente, discute-se a analogia de cidade-pátria, que tem a necessidade de ser sempre pensada como um espaço-sujeito coeso, no qual todos os atores públicos e privados, bem como a sociedade civil, estejam em sintonia. Para Vainer (2000), uma das primeiras artimanhas da transformação da cidade em cidade-pátria é estabelecer um pensamento homogêneo de consciência acerca das dificuldades em curso naquela localidade. A partir disso, é possí- 
vel trabalhar uma educação para a forma de cidade que se deseja construir, eliminando os interesses particulares dos atores e formando um projeto “coeso, legítimo e universalmente aceito" (VAINER, 2000, p. 93) que pode ser levado adiante. Esse trabalho pode tomar forma a partir de um representante político, um líder comunitário carismático ou, por que não, cartilhas de orientaçóes de ações para o desenvolvimento local.

A união para a salvação da cidade transforma-se em patriotismo cívico, resultado de sucesso do projeto de conscientização problemática. Passa-se, dessa forma, a mostrar a cidade-empresa e a cidade-produto como condiçóes de paz social. Cabe lembrar que não necessariamente esse projeto é desempenhado pelos administradores públicos ou pelas figuras politicamente legítimas das cidades, mas também podem partir de atores privados, lideranças urbanas ou indivíduos de importância no cenário local. A condição para o sucesso, de acordo com Vainer (2000), baseia-se mais no poder carismático da figura orientadora do que da sua posição de importância no cenário político local. Por fim, Vainer (2000) expóe o desmantelamento da cidade como espaço da política, tornando-se uma cidade "unida pela produtivização e competiçãao" (VAINER, 2000, p. 98).

A relação das analogias constitutivas de Vainer (2000) com o Estado, as políticas de desenvolvimento regional e a região fronteiriça se dá a partir do momento em que, observando casos específicos da fronteira do Rio Grande do Sul, é possível notar que os modelos de desenvolvimento tomados como promissores também chegam a essas regióes e, nesse caso específico, passam a figurar como doxa (Cf. Bourdieu, 1977). Com isso, pode-se notar que Jaguarão começa a performar analogias constitutivas que Vainer elaborou embasado em cidades que nada têm em comum com a realidade fronteiriça do Sul do Rio Grande do Sul, mas que, a partir desse ideal naturalizado de crescimento e desenvolvimento, tornam-se um receituário universal.

\section{A FRONTEIRA DE JAGUARÃO - RS}

Nas fronteiras do Rio Grande do Sul, no período de escopo desta pesquisa, entre 2009 e 2016, a economia local baseava-se na agricultura, pecuária e nos serviços. Isto, somado à distância dos centros financeiros do país, à cultura, entre outras características, parecia contribuir para fazer surgir uma expressão muito comum na região: cidade esquecida no tempo.

À época, como supramencionado, a maior temática econômica em pauta na cidade girava em torno dos desdobramentos do Projeto de Lei no 6.316, apresentado ao Congresso Nacional em 2009, tratando sobre a abertura de free shops no lado brasileiro das fronteiras internacionais. No documento, 
as justificativas trabalhadas versavam sobre a necessidade de diversificação $\mathrm{da}$ economia nas cidades fronteiriças, que acabam pormenorizadas frente às irmãs do lado oposto, uma vez que estas com o comércio diferencialmente tratado na questão tributária, competiriam com as irmãs brasileiras deixando-as em desvantagem.

Posto que a abertura desses empreendimentos visava à dinamização das atividades econômicas das cidades em questão, uma série de argumentos que afetam e alteram o funcionamento de toda a lógica desses espaços vinham sendo postos em discussão por distintos atores sociais locais (representantes públicos, a sociedade civil, os empresários, a mídia etc.).

Algumas dessas discussóes tomavam por base o exemplo dos free shops uruguaios, instituídos pelo governo em 1986, que tiveram sua primeira abertura nos municípios de Chuy (divisa com Chuí-BR) e Rivera (divisa com Santana do Livramento-BR), caracterizando-se pela venda de produtos com isenção fiscal ao consumidor estrangeiro, não sendo permitida a compra por uruguaios. Em Rio Branco, cidade de fronteira separada da brasileira Jaguarão pela Ponte Internacional Barão de Mauá, a primeira loja teve sua abertura em 2003.

A respeito disso, Miranda (2010) descreve a abertura dos free shops uruguaios como uma solução econômica genuína que deu vida a um setor peculiar. Ao pensar nas motivaçóes do governo uruguaio quanto a instalação dos free shops, é possível encontrar alguma semelhança com o caso brasileiro. A medida, tida como oportunidade para compensar os frequentes ciclos econômicos desfavoráveis que as cidades de fronteira uruguaias sofriam (devidos, na época, a taxa de câmbio com o Brasil), baseava-se (e ainda se baseia) na importação de modelos de localidades tidas como desenvolvidas, onde se observa uma demanda de produtos de alta qualidade e, por que não, bens de luxo (MIRANDA, 2010). O desenvolvimento local, no entanto, não se desdobrou como o esperado. Assimetrias sociais são claramente visíveis quando se compara as zonas de instalação dos free shops uruguaios com a localização residencial da cidade Rio Branco, por exemplo. De volta ao caso brasileiro, ainda que houvesse a expectativa em torno dos empreendimentos, Oddone e Prado (2015) destacam que avaliaçóes sobre o real impacto da instalação dos free shops para as cidades fronteiriças são incipientes.

\section{SINCRONISMOS TEMÁTICOS: O PROCESSO DE ABERTURA DOS FREE SHOPS E A POTENCIALIDADE DOS EVENTOS}

Como descrito, uma das propostas de desenvolvimento na região se respaldava a partir da abertura dos free shops do lado brasileiro das fronteiras inter- 
nacionais. Em Jaguarão havia um discurso bastante homogêneo que performava e dava sentido a tal enredo, constituindo-se uma doxa local a partir de uma ação, nos anos 1990, de uma moradora local. De acordo com o agente 3:

O principal mobilizador dos free shops a nível nacional é de Jaguarão, uma representante da sociedade civil que há muitos anos começou essa discussão de que já se observava exemplos de zonas francas como no Amazonas, onde ela morou, e trouxe a experiência para cá porque enxergava aqui [a fronteira] como um espaço apto a uma situação semelhante de distanciamento dos centros, enfim, e achava que poderia ter aqui algum tipo de zona franca implantada, como forma de resolver as questôes de desenvolvimento. (Agente 3).

Entre 1986 e 2003, com a abertura dos free shops uruguaios, a ideia tomou forma e passou a servir de motivação para conversas com o poder público. Diz-se que muito pelas motivaçôes dessa comerciante, em conjunto com projetos de lei e propostas ao Governo Federal, em 2012 a lei de abertura dos free shops brasileiros foi sancionada. A partir desse momento, já no que tange ao poder público local, o protagonismo passa a ser do prefeito de Jaguarão, já que, por estar no poder, tomou a frente das negociaçóes e reuniões de âmbito nacionais. Na Secretaria de Planejamento e Urbanismo, a maior envolvida no processo, falou-se sobre a legislação municipal, datada de $2014^{3}$, que criou um Grupo Técnico para a regulamentação e implantação dos free shops. A principal preocupação destacada pelo agente 3 versava sobre a construção de um zoneamento para a implementação das lojas, visando a integração deste comércio à zona urbana da cidade, destacando-se o exemplo negativo de Rio Branco, cidade vizinha, em que a zona onde foram instaladas as lojas dos free shops não interage e não dialoga com a parte urbana da cidade.

Durante os anos de 2014 e 2015, uma série de assembleias e audiências públicas tomou curso nas cidades fronteiriças, com o intuito de debater a temática. Em julho de 2015, aconteceu o maior destes eventos até então, em Jaguarão, onde o então prefeito local foi escolhido pelos representantes das 10 cidades de fronteira do Rio Grande do Sul como coordenador do Fórum de Prefeitos de Cidades Gêmeas do RS, sendo porta voz das demais cidades e responsável também por redigir a Carta de Jaguarão ${ }^{4}$, documento que expressava os interesses dos envolvidos no processo a ser direcionado aos governos Estadual e Federal (PREFEITURA MUNICIPAL DE JAGUARÃO, 2015). Ainda nesse evento, o prefeito declarou que

Com a implantação da zona franca nos munícipios brasileiros de fronteira, poderemos revitalizar nossas potencialidades, além de valorizar os pequenos e médios empresários através do fomento à mão de obra local, na prestação de serviços e em hotelaria. (PREFEITURA MUNICPAL DE JAGUARÃ̃, 2015, $\mathrm{S} / \mathrm{P})$. 
Em sintonia à ideia de potencialidade, o agente 4 declarou que os free shops, atrelados a ideia de utilização do centro histórico da cidade, são um investimento àquilo que a cidade tem a oferecer. Ele afirma que "nós [a prefeitura] começamos a investir naquilo que é potencial da cidade, e o que é potencial na cidade? O turismo!", além de destacar que "todo mundo dizia que [nós, a prefeitura] tínhamos que trazer indústria, mas essa na verdade não é a nossa vocação!”. O agente 5, ao ser questionado, no entanto, não demonstrou muito interesse no assunto. Para ele, o perfil de turismo da cidade, mais voltado à área cultural, colide com o perfil do turista de compras, mais "predatório" (Cf. Vainer, 2000), mas os free shops seriam um passo necessário no momento, para que posteriormente fosse possível pensar em outras atividades econômicas.

Durante todas as conversas e entrevistas, eram enfáticos os comentários sobre a centralidade do prefeito no processo de instalação dos free shops. Os agentes diziam que "essa é uma pauta do prefeito" (agente 2), "quem está à frente do processo é o prefeito" (agente 6), "o prefeito pode te dar uma aula sobre isso" (agente 5), "uma luta que o prefeito tem levado enormemente" (agente 4) e, inclusive, o próprio prefeito expressou-se dizendo que havia "tomado a frente" do processo.

Era possível observar um clima de prosperidade ainda na discussão, cabendo destacar a fala do agente 4 , versando sobre a possibilidade de a instalação das lojas "dar um salto na geração de emprego e renda incrível [para a cidade]". A prosperidade aparente remetia a discussões como a de Schumpeter (1988), ao discorrer sobre alteraçóes na ordem econômica da sociedade sem necessariamente o acarretamento de mudanças qualitativas. Esse ideal de desenvolvimento voltado ao desenvolvimento econômico traz ainda reflexóes acerca da pretensão de tornar Jaguarão uma cidade-produto, em referência a Vainer (2000), a partir da oportunidade de se apresentar vendível como espaço interessante para o estabelecimento de empreendimentos relacionados ao comércio de free shops e, assim, um polo de turismo de compras.

Ainda nos assuntos em que havia concordância, o Carnaval da cidade se destacou. Nos anos que antecederam a pesquisa a cidade de Jaguarão era conhecida como destino carnavalesco do estado do Rio Grande do Sul. Principalmente nas falas dos agentes 1 e 2 , o evento era tido como a maior expressão de integração dos moradores com a cultura local. Afora a abordagem cultural do evento, o agente 2 destacava que apesar do sucesso dos últimos anos, ainda existia a necessidade de uma "maior profissionalização dos envolvidos", para que a atividade oferecesse trabalho e retornos financeiros não apenas durante os três meses que envolvem o preparo e o acontecimento do evento, mas durante todo o ano. Apesar de não explicitar uma visão empre- 
endedora, o tom do agente 2 deixava clara uma visão de mundo competitiva, na qual o padrão de profissionalização guia as relações comerciais e orienta os indivíduos a seguir formas legitimadas de prestação de serviços para fazer parte do processo de desenvolvimento local.

$\mathrm{O}$ agente 4 também mencionou o comércio de vendedores ambulantes durante o Carnaval, destacando o trabalho feito pelo poder público para a organização, qualificação e profissionalização destes trabalhadores, criando um cadastro municipal e outras ferramentas de controle da atividade. Ligando a temática do Carnaval com outras abordadas durante a entrevista, o agente 4 ainda afirmou que "isso tudo aumenta a autoestima dos moradores e da cidade, e pra tu ter ideia o número de micro e pequenos empresários cresceu, no ramo de serviços, e isso fez com que [a vida dos moradores] começasse a melhorar”. Esse discurso se assemelha muito às ações e programas do Governo Federal, como, por exemplo, o Programa Nacional de Acesso ao Ensino Técnico e Emprego (Pronatec) em eventos como a Copa do Mundo de 2014, que fornecia educação técnica visando a profissionalização daqueles que poderiam, de alguma forma, se beneficiar com o evento esportivo (BRASIL, 2012c; 2012d).

\section{DISSONÂNCIAS: O RIO JAGUARÃO E ASPECTOS DA RELAÇÃO BINACIONAL}

Uma das temáticas menos destacadas durante as entrevistas foi a relação do Rio Jaguarão com o processo de desenvolvimento em curso na cidade, trazendo tanto a relação com o turismo como a construção da segunda ponte. $\mathrm{O}$ Rio, fronteira da cidade brasileira com Rio Branco, no lado uruguaio, dispóe de orla em ambas as margens, espaços utilizados para pesca, lazer e descanso. $\mathrm{O}$ agente 2, depois que a entrevista já havia sido encerrada e o gravador desligado, lembrou que havia uma empresa de fora de Jaguarão preparando-se para iniciar passeios turísticos no rio, aparentando animação com a possibilidade de tal forma de lazer ainda não explorada via âmbito privado.

O agente 7, por outro lado, discorreu sobre os projetos de revitalização da orla do lado brasileiro, em curso há vários anos, pretendendo qualificar o espaço com iluminaçóes, bancos, quiosques etc. Para ele, a ideia apresenta falhas pois, em determinada altura da orla, encontra-se uma comunidade periférica que tem como atividade principal a pesca. A questão principal abordada dizia respeito à viabilidade de um projeto que pretende alterar as características naturais do espaço sem a aparente consulta aos maiores afetados pelo processo. $\mathrm{O}$ agente 7 também entendia que, caso a revitalização acontecesse, a comunidade pescadora poderia pensar que "os caras tão 
falando que aquilo é um espaço público, que aquilo me representa, mas eu olho e eu não reconheço', então a gente [a prefeitura] tá falando de um processo inverso, de um processo de pertencimento que na verdade é afastamento...”. A temática remete às complexas formas de diálogo frente às intençôes e justificativas econômicas (neste caso, dos agentes do poder público) para os projetos, frente a participação da comunidade local nesses processos de formulação de políticas e ações ao espaço público (BENKENSTEIN, HERMANY \& SODER, 2010).

A binacionalidade, bem como as relações pessoais e institucionais com o Uruguai, foram os assuntos que curiosamente mais divergiram, ao mesmo tempo em que apresentavam equivalência nas falas. Apesar de os agentes 1 , 2 e 6 concordarem que a troca entre os dois países é muito intensa no núcleo Jaguarão - Rio Branco (fato facilmente observado em tarefas cotidianas que envolvem relaçóes com moradores de ambos os lados), o fator institucional dessa relação binacional divergiu. $\mathrm{O}$ agente 2 demonstrou preocupações com o formato das relaçóes entre os dois municípios. Para ele, muito pautados em relações pessoais, os acordos e cooperaçóes formulados ficavam à margem da informalidade, e uma vez que os mandatos e gestóes eram encerrados e administrações eram trocadas, perdiam-se. Pontualmente, afirmou que

A grande questão, a grande chave, é que as relações se dão ainda num âmbito e num aspecto muito informal... ou seja, elas estão vinculadas ainda a relaçôes pessoais que a gente consegue criar, porque a relação institucional ela se dá muito a nível de governos federais. (Agente 2)

A isso, soma-se o fato de que as eleiçóes presidenciais e municipais do Uruguai acontecem a cada cinco anos (FLORES DAPKEVICIUS, 2011), enquanto no Brasil são quatro anos, e as instâncias presidenciais e municipais são eleitas de forma intercalada, com diferença de dois anos. Com isso, torna-se complexa a coordenação de políticas e acordos que perdurem através dos anos.

Apesar da insatisfação do agente 2 com a fragilidade da relação binacional, ele também afirma que "nesses últimos anos a gente [os agentes do poder público] começou a usar esse aspecto da binacionalidade como uma perspectiva de desenvolvimento, e até de venda da cidade, vamos dizer assim”. O agente 2 referia-se à atração de turistas com enfoque na possibilidade de destaque dessa particularidade e, também, afirmando que "o Instituto Federal Sul-rio-grandense ${ }^{5}$ só veio se instalar [em Jaguarão] porque nós [a prefeitura] usamos como argumentação a binacionalidade".

O agente 1, por outro lado, não discorreu sobre a falta de formalidade nas relaçốes binacionais. Todas as referências à binacionalidade por ele apre- 
sentadas eram positivas. Fez referência, por exemplo, ao país vizinho como modelo, afirmando que "[nós, os agentes do poder público] trabalhamos fortemente o tema de fronteira inspirados pelas políticas do Uruguai e os free shops uruguaios". Também tratou da educação superior no município, mencionando o "debate dentro da diretoria da UNIPAMPA para trazer cursos que dialogassem fortemente com a temática fronteiriça”. Também destacou como uma das "grandes conquistas do nosso governo, a escola técnica IFSul, [como] a materialização da binacionalidde com o país vizinho, nossa segunda pátria, a necessidade de atender a população fronteiriça, os uruguaios, em sua plenitude”.

Enquanto a fala do agente 2 demonstra preocupação sobre o assunto, posta a sua candidatura nas eleiçóes municipais de 2016, o agente 1 parece tratar da temática com tranquilidade, de forma a dar entender que na sua gestão a binacionalidade foi tratada como exemplo e oportunidade. A ideia de fronteira do agente 1 e da interação do lado brasileiro com o uruguaio parece mais relacionada ao debate de fronteira como a diferenciação de boundaries e borders ${ }^{6}$ feitas por Sennett (2011), em que o conceito de boundaries exclui, limita, enquanto o conceito de borders possibilita o diálogo, o contato e a dinâmica.

Para os entrevistados, de modo geral, a ideia de fronteira como região esquecida, tal qual descrito nas publicações oficiais do Governo Federal, inexiste. $\mathrm{Na}$ percepção destes, a fronteira tem relevância no cenário nacional, mas não da forma com que gostariam que tivesse. Ao destacar o fator institucional, por exemplo, deixam claro que o que falta é o reconhecimento daquele espaço como interação de duas localidades aparentemente separadas, mas que na prática, têm uma relação unificada. Para justificar tal ideia usaram como exemplo, os postos da aduana, que se encontram nas extremidades da Ponte Barão de Mauá: para os entrevistados isso descaracteriza a relação que vem se tentando melhorar diariamente, e o ideal seria que as aduanas estivessem na saída de cada cidade para o seu próprio país, oficializando a integração que, na prática, já acontece entre seus moradores.

\section{ANACRONISMOS TEMÁTICOS: PATRIMÔNIOS LOCAIS, O PAPEL DA ATIVIDADE TURÍSTICA E O PROGRAMA DE PROMOÇÃO DO DESENVOLVIMENTO DA FAIXA DE FRONTEIRA}

Além dos free shops, temática voltada à questão econômica, também se enfatizou o patrimônio e a atividade turística, temáticas discordantes presentes em todas as entrevistas, evidenciando uma tensão entre os agentes. $\mathrm{O}$ município de Jaguarão recebeu, em 2013, 40 milhões de reais em verbas do PAC 
Cidades Históricas, destinados à reforma e requalificação de prédios históricos (PREFEITURA MUNICIPAL DE JAGUARÃO, 2013). Desde então, espaços como o Theatro Esperança e o Mercado Público, marcados pelo abandono e o esquecimento, passaram a ser reestruturados.

As divergências ocorriam nas opinióes acerca da finalidade das reestruturações dos espaços. $\mathrm{O}$ agente 1 afirmava a necessidade de tornar os locais lucrativos, com venda de ingressos para peças de teatro, aluguéis de boxes no mercado para restaurantes, bares e lojas, trazendo a ideia de desenvolvimento a partir de um ponto de vista estritamente econômico. Enquanto isso, o agente 6 preferia pensar no uso desses espaços para ações gratuitas voltadas aos moradores, como oficinas e propagação da cultura local, em sintonia com o agente 2, que defendia uma visão de reconquista da autoestima do jaguarense, mostrando o que a cidade tinha de interessante para se fazer e conhecer. Para ele, era necessário "trabalhar para que as pessoas acreditem [nas potencialidades]", porque quando "a gente [poder público] conseguir romper com essa barreira, da crença das pessoas, é aí que a gente, de fato, vai começar a se tornar uma cidade melhor, mais desenvolvida”. Ao mesmo tempo em que o discurso do agente 2 relaciona-se a ideia de cidade-pátria (VAINER, 2000), pensando em um trabalho de conscientização e convencimento do pertencimento da população ao espaço, também se pode fazer um paralelo com a ideia de indivíduo como investimento e investidor, de forma a ser capaz de administrar a si mesmo como propulsor do desenvolvimento de suas próprias atividades e condutas (Cf. Vainer, 2000) em sintonia com o pensado para a cidade pelo poder público local.

Falas como "nós precisamos vender a cidade!" e "vamos qualificar o nosso patrimônio para receber os visitantes", do agente 5, chocavam-se com momentos em que este também se preocupava com o que chamou de "usabilidade? em longo prazo", uma vez que nem todos os turistas seriam novos turistas. Esses impasses sinalizavam certa semelhança às analogias constitutivas de Vainer (2000), em referência à necessidade de transformar Jaguarão em um produto interessante e qualificado, capaz de conquistar atençóes externas e passível de se tornar lucrativo, assim como uma empresa de sucesso. Também, essa urgência em trazer atividade turística qualificada à cidade une-se aos ideais de desenvolvimento nacional, uma vez que se vem pensando nas "contribuiçóes do setor para o desenvolvimento econômico, social e a erradicação da pobreza” no Brasil (BRASIL, 2013, p. 8). Em outro momento, a menção, pelo agente 3, ao PAC Cidades Históricas como "uma oportunidade incrível que o Governo Federal vem dando às cidades”, denota o convencimento do sucesso das políticas do Governo Federal direcionadas ao crescimento (como o próprio nome do programa diz) dos espaços, teoricamente, necessitados. 
As falas do agente 7 , referentes à requalificação do patrimônio não só material, mas também da autoestima dos moradores, remetem à ilusão da cidade-pátria (VAINER, 2000), onde tem-se um discurso harmonioso que acaba por servir aos propósitos, mais uma vez, da promoção do espaço. Ele demonstrou desconforto com a cultura de patrimonialização apenas material, que faz com que se esqueça dos patrimônios imateriais. Discorreu sobre o retorno financeiro de um patrimônio edificado, passível de visitações, para um patrimônio apenas no imaginário, pensando nessa como uma das motivações das instituições públicas a dar mais atenção a um do que a outro.

Além disso, o agente 3, ao preocupar-se com o zoneamento dos free shops brasileiros, também, une-se ao discurso do agente 5 , esperando que o espaço dedicado a esses empreendimentos continue a ser o espaço destinado ao centro comercial, local em que também se situa o centro histórico e, assim, os atrativos da cidade. Também sobre essa discussão, o agente 7 opina, destacando que a uniáo do centro histórico da cidade com o zoneamento dos free shops leva à necessidade de uma compreensão da legislação acerca do patrimônio edificado e da utilização, por exemplo, de placas e luminosos por estabelecimentos comerciais que estejam instalados nesses espaços.

Para o agente 7 não basta, dessa forma, reformar os prédios históricos e concluir que o trabalho patrimonial está pronto. Para ele, o processo de conscientização da população, bem como de pesquisas para averiguar o que os moradores esperam para aquele espaço é essencial. Ainda, quando questionado sobre o início do processo de restauração dos patrimônios municipais, o agente 7 declarou que, mesmo o debate tendo começado em 2004, o prefeito atual, das gestóes 2009-2012 e 2013-2016 "foi o cara que conseguiu captar... acelerar esse processo... na verdade ele é o pai da criança, desse processo de patrimonialização do município”.

A despeito disso, o agente 1 afirma que "o PAC Cidades Históricas dialoga principalmente com o turista que vem de fora, então além dos restauros [sic], a gente precisa de outras coisas, restaurantes... para não ser um espaço meramente de contemplação". Em sintonia com isso, o agente 6 também destacou que os free shops podem ser um grande desafio para o turismo de Jaguarão, uma vez que, normalmente, em cidades históricas, as pessoas chegam em busca de cultura e acabam consumindo mercadologicamente. Em Jaguarão, a motivação principal das visitas seria o consumo, e os gestores públicos, bem como os moradores, teriam que trabalhar em conjunto para que esses visitantes encontrassem as expressốes de cultura disponíveis para visitação. Para o agente 5 , no entanto, a ideia de que o turismo precisa ter melhor relação com o setor privado é essencial, então para ele os processos estavam "no caminho certo". 
Finalmente, quando questionados a respeito das orientações do Governo Federal, mais especificamente da PNDR, do PDFF e da Cartilha de Faixa de Fronteira, curiosamente nenhum dos entrevistados tinha conhecimento prévio do documento.

O agente 2 afirmou que a PNDR abriu "um pouco" o debate sobre pensar-se a região fronteiriça de uma nova forma, não mais com viés militarista e de segurança nacional, mas sim com a possibilidade de um desenvolvimento a partir da binacionalidade. Essas informaçóes não perpassam o documento, uma vez que ali, como mencionado anteriormente, o foco é assumir uma dívida histórica do Governo Federal com regiões esquecidas pelo processo de desenvolvimento brasileiro. Ao final dessas constataçôes, o agente 2 afirmou que "essa relação de enxergar a faixa de fronteira diferente é um pouco o que tá no Programa...", deixando claro que não tinha conhecimento das diretrizes da Política, mas havia explanado algumas das especificidades e preocupações das cidades fronteiriças de forma mais homogênea. Para ele, na instância municipal, é preciso

fazer com que as pessoas introjetem [sic] um pouco essa ideia do desenvolvimento, e para isso a gente [os representantes do serviço público] tem que qualificar a relação com as pessoas, por um lado, e os serviços públicos por outro, mais do que investir em infraestrutura (...) então a gente precisa, digamos assim, remontar essa equação para que as pessoas se apropriem da cidade (Agente 2)

O agente 1, por outro lado, foi além na fala sobre o seu entendimento da PNDR e da Cartilha de Faixa de Fronteira. Ele afirmou que o município se envolvia com as decisóes tomadas no âmbito federal, participando das Reuniôes de Alto Nível - RANS, em que acontecem fóruns de debate. Para ele, são espaços necessários para a criação e consolidação de políticas públicas de convivência entre os países vizinhos, citando meios alternativos como o uso do Fundo para a Convergência Estrutural do MERCOSUL (FOCEM). Finalmente, expressou sua opinião quanto à atuação do ex-presidente Luiz Inácio Lula da Silva ao posicionar-se frente à valorização da integração e relação com os países da América Latina em uma perspectiva bastante popular. Novamente, nenhuma dessas temáticas fazem-se presentes na PNDR, bem como não fazem parte da alçada do Ministério da Integração Nacional. As RANS integram programaçóes das Organizaçóes das Naçóes Unidas (ONU), enquanto o FOCEM, apesar de ser destinado a financiar projetos, entre outros, de desenvolvimento da competitividade, era administrado na época, no Brasil, pelo Ministério do Planejamento, Desenvolvimento e Gestão (BRASIL, 2015). 
O agente 1 ainda afirma que "sem falsa modéstia, eu fui o gestor público [de Jaguarão] que trabalhou mais fortemente o tema fronteiriço como política de governo", uma vez que "[na minha gestão] assumimos a linguagem das políticas de fronteira, transversalizando [sic] com tudo aquilo que a cidade tem de potencial em relação ao tema fronteiriço”. Ainda assim, mesmo escolhido pelas demais cidades fronteiriças do Rio Grande do Sul para coordenar o debate sobre as aberturas dos free shops brasileiros frente ao Governo Federal, o agente 1 não demonstrou conhecer profundamente o documento oficial de orientação de desenvolvimento para esses espaços. Isto posto, observou-se o descompasso existente entre a diretrizes de uma cartilha elaborada pelo Governo Federal e a gestão local, que através de seu histórico e trajetória, faz com que a cidade configure uma doxa de seu desenvolvimento e vocação.

O que as entrevistas remontam é que a divergência em relação ao pensamento de desenvolvimento acontece porque os atores deste enredo têm determinada doxa sobre o que é desenvolvimento, demonstradas pelas categorias em descrição nesse texto, que não estão em total sintonia com o que o PDFF propóe. Ainda que não em total sintonia, aspectos de cooperação subjetiva legitimam o desenvolvimento, mesmo que ele não tenha uma definição objetiva traçada por todos, como solução de todos os problemas locais. Essa legitimidade pode ser compreendida, talvez, a partir de um discurso de lutas entre atores com certa confiabilidade no cenário (BOURDIEU, 2007; 2008).

Mesmo que o agente 1 afirme que "nós [os agentes do poder público] procuramos nos aproximar e sermos protagonistas de todos os temas relacionados com as questôes fronteiriças”, fica clara a primazia do assunto dos free shops. Assim também foi o processo uruguaio da década de 1980. Com isso essa se tornou a principal discussão das entrevistas, atrelada aos elementos que a compóem, não deixando espaço para que se pensasse ou se tomasse conhecimento de outras promessas de oportunidades para a região fronteiriça.

De modo geral, as temáticas do processo de patrimonialização, do turismo e do conhecimento dos documentos oficiais do Governo Federal, mesmo que de extrema importância na construção desta pesquisa, podem demonstrar como a falta de coesão nas opiniốes dos atores entrevistados está ligada, de uma forma ou de outra, ao maior domínio que estes têm sobre os assuntos. No caso do processo de patrimonialização e turismo, como as restauraçôes e ocupações ainda não estavam completamente finalizadas, foi possível que os envolvidos expressassem mais ideias e julgamentos sobre seus destinos e finalidades. Além disso, estando o prefeito ocupado em focar-se em outras temáticas, como a instalação dos free shops, o policiamento dos atores para opinar a respeito destes assuntos era menor. Quanto às orientaçóes do Governo 
Federal e o pouco ou nenhum conhecimento dos agentes 1 e 2 , notou-se algo relevante: mesmo sem orientarem-se pelas diretrizes oficiais, ambos apresentam em suas falas, ainda que de formas diferentes, elementos, ideias e açóes presentes nos documentos. Mesmo que não caiba julgar o conhecimento dos atores frente às orientaçóes, parece ser importante esse destaque para descrever uma determinada lógica de ideal nacional, uma doxa.

Foi possível notar que existe uma "luta" objetiva pela definição de desenvolvimento que, entretanto, configura-se como subjetiva. O surgimento das divergências, no entanto, reforça a existência de uma cooperação subjetiva quando todos os atores municipais falam de desenvolvimento e legitimam essa doxa (Cf. Bourdieu, 1977) como a solução de todos os problemas no âmbito local. Problemas esses que, talvez, nem existissem se o debate de desenvolvimento não fosse constantemente levantado como tão emergente e condenado a seguir um receituário universal, que, de certa forma, desconsidera as localidades como espaços diversos e repletos de especificidades que, não necessariamente, as tornam menos importantes que outros espaços eleitos como mais dinâmicos ou economicamente relevantes. E assim, também, o modelo de referência que toma forma frente essa cooperação é a analogia de cidade-pátria (VAINER, 2000).

\section{CONSIDERAÇÕES FINAIS: PERSPECTIVAS DE DESENVOLVI- MENTO E DOXAS LOCAIS E NACIONAIS}

De modo geral, os dados contribuíram, principalmente, para uma percepção das relações de poder dentro do serviço público municipal, mostrando que para além de uma hierarquia de valores frente às orientações pró-desenvolvimento do Governo Federal, a doxa (Cf. Bourdieu, 1977) de desenvolvimento municipal ganha certo conteúdo mais específico e incorporado do que o pensado pelo âmbito federal. Exemplo disso é a maneira como foram apresentadas as temáticas desenvolvidas com os agentes: de forma a concentrar assuntos em que as opinióes convergiam, parcialmente divergiam e divergiam por completo. Isso de forma a demonstrar que mesmo dentro do governo municipal havia formas e olhares diferentes frente ao receituário universal.

Quanto à realidade das discussóes sobre desenvolvimento na cidade de Jaguarão, é necessário questionar o quanto se tem conhecimento e informação a respeito de processos semelhantes vividos previamente em outros espaços. A confiança de que a implantação dos free shops alavancará a economia, por exemplo, desconsidera o histórico da cidade uruguaia vizinha, Rio Branco. A esperança dos patrimônios como propulsores da atividade 
turística, também, não é pensada de forma a relembrar processos em estagnação em municípios próximos que investiram em seus patrimônios como forma de atração turística, mas não obtiveram resultados consideráveis com essas açóes. Um dos questionamentos gira em torno do clima de prosperidade ser fruto de uma exagerada confiança nas capacidades e potencialidades do município ou talvez, advir de um convencimento quase generalizado que parte de um pequeno grupo detentor de voz legítima para tal. Além disso, pode-se pensar nessa discussão de forma mais complexa, considerando a soma e a convergência desses aspectos em uma complexa fé no progresso, formando a doxa (Cf. Bourdieu, 1977), isto é, a crença de um "desenvolvimento" sempre pautado a partir de aspectos econômicos. Essa complexa configuração de promessas de oportunidades se reflete no senso comum local, que afugenta os fantasmas da estagnação e se apresenta como esperança de solução de todos os males políticos, econômicos, culturais e sociais.

A competitividade, outra temática que figurava como plano de fundo em diversas falas dos agentes, parte de um estímulo intimamente relacionado à noção de um cenário neoliberal onde a adoção subjetiva da analogia cidade-empresa (Cf. Vainer, 2000) passa a ser, dessa forma, (mesmo que simbólica) central para a concretização do que é desenvolvimento. Quanto a isso, parece haver certo esforço tanto dos poderes públicos quanto da sociedade civil para o estabelecimento de um ideal competitivo. Documentos como Índice de Competitividade do Turismo Nacional, as pesquisas dos Hábitos de Consumo do Turismo no Brasil, os Relatórios de Pesquisa de Mercado e os Boletins de Desempenho Econômico do Turismo reforçam a necessidade, no caso do turismo, de renovar-se e repensar-se a todo tempo, bem como outros âmbitos como a educação, o esporte, a ciência etc., passam pelos mesmos processos.

Finalmente, o aparente desconhecimento das publicaçóes oficiais do Governo Federal quanto às orientaçóes pró-desenvolvimento para o espaço fronteiriço não é surpreendente. $\mathrm{O}$ discurso linear que acompanha a fala dos atores, mesmo sem conhecimento, fazendo referências às propostas presentes nesses documentos, leva a refletir: será possível falar de um ideal nacional de desenvolvimento, que figura de forma tão natural no pensamento brasileiro que não precisa, de fato, ser justificado ou ter referência, mas circula e se reproduz de forma autônoma e, por que não, utilizando-se da ideia de Schumpeter (1988), endógena?

Parece existir, na fronteira, a tentativa de um resgate histórico de desenvolvimento pautado por incursóes e esperanças às atividades que prosperam em outras localidades, como o princípio da discussão de similaridade com o processo de estabelecimento da Zona Franca de Manaus e a aposta no 
turismo. É possível traçar uma inter-relação a isso às diretrizes do Governo Federal, posto que as orientações tratam da fronteira como esquecida historicamente e demandam urgência em encontrar potencialidades e vocaçóes internas para deixar no passado o estigma da terra esquecida. Pensando em Vainer (2000), nota-se a emergência do Governo Federal em transformar as cidades que a PNDR e o PDFF abrangem em alguma das, ou todas, analogias de empresa, produto ou pátria (VAINER, 2000).

A construção da noção de desenvolvimento em Jaguarão pode diferir da construção de desenvolvimento em outros espaços, sejam eles fronteiriços ou não, quando levando em conta a interdependência que configura as relações sociais, os comportamentos individuais, as motivaçóes e as particularidades não só do espaço, mas também dos atores interessados nesse processo (ELIAS, 1999). Ainda, não desconsiderando os aspectos interacionais, relacionais, dependentes de subjetividades que ultrapassam os limites geográficos e políticos do espaço fronteiriço (SENNETT, 2011; 2013), esse discurso ao desenvolvimento vem carregado de maior interdependência (ELIAS, 2000; 2001) e relatividade do que é aparente. Também, cabe lembrar que em Elias (1999; 2000; 2001) são os atores que configuram diretrizes e debates, de forma independente, o que pode ser relacionado à realidade de Jaguarão frente aos documentos oficiais do Governo Federal. Ainda, unindo-se a essa compreensão, é possível compreender como a doxa do desenvolvimento em Jaguarão tem características diferentes da doxa do desenvolvimento veiculada pelo Governo Federal ou, quem sabe, observada em outras cidades: a figuração dos atores de Jaguarão como relacionais e interacionais de forma específica e interligada a realidade local (Cf. Elias, 2001), dá forma a uma configuração característica daquele espaço e daquela dinâmica.

Apesar das especificidades da doxa do desenvolvimento em Jaguarão, existe certa convergência simbólica e legítima que faz com que esta esteja em sintonia subjetiva com as demais doxas construídas pelo país. Entende-se que isso se dá como reflexo da compreensão da doxa de desenvolvimento das cidades como uma união das analogias constitutivas de Vainer (2000), da fé no desenvolvimento, no sentido de "desenvolvimento econômico" com retornos "lucrativos" como solução de todos os problemas, da intervenção de políticas públicas e programas homogeneizados e da crença de que há potencialidade e, com isso, deve-se investir na competitividade.

Em Jaguarão, como talvez em inúmeras outras cidades de fronteira, ou inúmeras outras pequenas cidades distantes dos centros econômicos brasileiros, as coerçôes a respeito das políticas públicas nacionais parecem percorrer um longo e sinuoso caminho a partir das decisóes do Governo Federal. Esse caminho passa ou não pelo Governo do Rio Grande do Sul, e as coerçôes 
adentram de forma diluída na administração municipal, sendo finalmente incorporadas pelos atores locais sem muita possibilidade (ou, por que não?) interesse em compreender de onde vêm os ideais e crenças tidos como naturais à sociedade.

Pode-se questionar, dessa forma, qual a motivação de tais programas e a quais grupos econômicos, políticos, sociais, privados (ou não) eles intencionam beneficiar - seja em aspectos de crescimento econômico, seja em prol de um reconhecimento social, seja em vias da promoção de um ideal, entre as mais diversas motivações que se pode ou não imaginar na dada situação. Ainda que esse não seja um debate recente, tampouco exclusivo dos programas de desenvolvimento ou desenvolvimento regional, ele permite a reflexão acerca do debate de políticas públicas nacionais e da necessidade de relacionar este tema com os atores e contextos específicos de cada realidade.

\begin{abstract}
Notas
' Lojas de produtos com diminuição ou isenção de impostos, normalmente localizadas em áreas internacionais como aeroportos, portos ou navios de cruzeiros, no caso brasileiro.

${ }^{2}$ Os dados e reflexões contidos neste texto são fruto da dissertação de mestrado "Entre os fantasmas do passado e a crença no futuro: uma narrativa sobre as estratégias adotadas pelo governo de Jaguarão (RS) frente às diretrizes do Programa de Promoção do Desenvolvimento da Faixa de Fronteira", finalizada e defendida em 2017 no Programa de Pós-Graduação em Sociologia da Universidade Federal de Pelotas, subsidiada por bolsa CAPES.

${ }^{3}$ Lei Orgânica Municipal nº 6.008 de 28 de agosto de 2014.

${ }^{4}$ A Carta de Jaguarão foi um documento redigido pelo prefeito de Jaguarão ao Governo do Estado do Rio Grande do Sul e ao Governo Federal expressando o interesse das 10 cidades de fronteira do Rio Grande do Sul na abertura dos free-shops brasileiros. Não obstante, esse documento não foi citado em nenhuma entrevista, e não há informações oficiais sobre a sua redação no apanhado geral de informações disponíveis para consulta sobre o processo de abertura desses free-shops.

${ }^{5} \mathrm{O}$ Instituto Federal Sul-rio-grandense - IFSul tem uma parceria binacional com a Universidade do TrabaIho do Uruguai - UTU-CETP, que em 2017 completou 10 anos. Atuando em Santana do Livramento - BR e Rio Branco - UY, as instituições permitem que o aluno receba a dupla diplomação (Mais informações em: http://www.ifsul.edu.br/ultimas-noticias/787-programacao-alusiva-aos-dez-anos-de-parceria-binacional-do-ifsul-e-tema-de-reunioes, acesso em 17 de dezembro de 2016).

${ }^{6}$ Limites e fronteiras, em tradução livre.

${ }^{7}$ Grifo das autoras.
\end{abstract}

\title{
Referencias
}

BENKENSTEIN, J. C.; HERMANY, R. \& SODER, R. M. O Empoderamento social e o poder local como instrumentalizadores na formulação democrática de políticas públicas municipais. In: SCORTEGAGNA, F.; DA COSTA, M. \& HERMANY, R. (Org.). Espaço local, cidadania e políticas públicas. 1. ed. Santa Cruz do Sul, 2010, v. 1, pp. 227-244.
BOSCHI, R. \& GAITÁN, F. Politics and development: lessons from Latin America. Brazilian Political Science Review, Rio de Janeiro, v. 4, Selected Edition, 2009.

BOURDIEU. P. Outline of a theory of practice. Cambridge: Cambridge University Press, 1977 
BOURDIEU, P. Questões de sociologia. Rio de Janeiro: Marco Zero, 1983.

BOURDIEU. P. O poder simbólico. Rio de Janeiro: Bertrand Brasil, 1989.

BOURDIEU. P. A economia das trocas simbólicas. São Paulo: Perspectiva, 2007.

BOURDIEU. P. A economia das trocas linguísticas: o que falar quer dizer. São Paulo: Universidade de São Paulo, 2008.

BOURDIEU, P. Sobre o Estado. São Paulo: Companhia das Letras, 2014.

BRANDÃO, C. A busca da utopia do planejamento regional. Revista Paranaense de Desenvolvimento, Curitiba, n. 120, pp. 17-37, 2011.

BRASIL. Ministério da Integração Nacional: Secretaria de Políticas de Desenvolvimento Regional. 2007. Política Nacional de Desenvolvimento Regional - PNDR.

BRASIL. Ministério da Integração Nacional: Secretaria de Desenvolvimento Regional. 2009a. Faixa de Fronteira: Programa de Promoção da faixa de Fronteira - PDFF.

BRASIL. Projeto de Lei $n^{\circ}$ 6.316, de 2009. Dispõe sobre a instalação de Free Shopping nas faixas de fronteira. 2009b.

BRASIL. Ministério da Integração Nacional: Secretaria de Desenvolvimento Regional. 2010a. Bases para uma proposta de desenvolvimento e integração da Faixa de Fronteira: Grupo de Trabalho Interfederativo de Integração Fronteiriça.

BRASIL. A PNDR em dois tempos: A experiência apreendida e o olhar pós 2010. Brasília, DF: Ministério da Integração Nacional (MI). Secretaria de Políticas de Desenvolvimento Regional, 2010b.

BRASIL. Ministério da Integração Nacional. 2011.

BRASIL. Ministério da Integração Nacional: Secretaria de Desenvolvimento Regional. 2012a. I Conferência Nacional do Desenvolvimento Regional: Documento de Referência.

BRASIL. Lei $n^{\circ}$ 12.723, de 9 de outubro de 2012.
BRASIL. Em coluna, Dilma Rousseff fala sobre Pronatec Copa. Portal da Copa, 2012c. Disponível em: https://bit.ly/3l37RoX. Acesso em: 21 jun. 2014.

BRASIL. Governo pretende qualificar $240 \mathrm{mil}$ até a Copa, diz presidenta. Portal da Copa, 2012d. Disponível em: https://bit.ly/2TC2J8E. Acesso em: 21 jun. 2014.

BRASIL. Ministério do Turismo. Plano Nacional de Turismo 2013-2016: O Turismo fazendo muito mais pelo Brasil. Brasília, DF, 2013.

BRASIL. Ministério do Planejamento, Desenvolvimento e Gestão: FOCEM. Fundo para a Convergência Estrutural e Fortalecimento Institucional do Mercosul (FOCEM), 2015. Disponivel em: https://bit.ly/3zIUoBa. Acesso em: 10 nov. 2016.

BRASIL. Decreto ${ }^{\circ}$ 9.810, de 30 de maio de 2019.

CARDOSO, M. L. Ideologia do desenvolvimento. Brasil: JK-JQ. Rio de Janeiro: Paz e Terra, 1978.

CASTELLS, M. \& BORJA, J. As cidades como atores políticos. Novos Estudos CEBRAP, $\mathrm{n}^{\circ}$ 45, pp. 152-166, 1996.

CENSON, D. Cidades de fronteira: a promessa de abertura dos free-shops brasileiros e as noções públicas do espaço Rio Grande do Sul-Uruguai a respeito deste processo. In: MICHELON, F. F. \& BASTOS, M. B. (Org). Fronteiras. Pelotas: Ed. da UFPel, 2019, pp. 9-25.

COSTA, M. A. Da razão instrumental à razão comunicativa: o percurso do planejamento na modernidade e as abordagens pós-positivistas. Cadernos IPPUR, Rio de Janeiro: Ippur/UFRJ, v. 22, n. 2, pp. 89-113، 2008.

DITTRICH, I. J. Apresentação, representação e metaforização das fronteiras: reflexões interdisciplinares. Textos \& Debates, Boa Vista, n. 22 pp. 31-45, 2012.

ELIAS, N. Introdução à Sociologia. Lisboa: Edições 70, 1999. 
ELIAS, N. Prefácio, Introdução e Considerações sobre o método. In: ELIAS, N. \& SCOTSON, J. L. Os estabelecidos e os outsiders. Rio de Janeiro: Jorge Zahar Editor، 2000, pp. 15-61.

ELIAS, N. A sociedade da corte: investigação sobre a sociologia da realeza e da aristocracia de corte. Rio de Janeiro: Jorge Zahar Editor, 2001.

FLORES DAPKEVICIUS, R. El sistema electoral en el Uruguay: ley de lemas. Uruguai: Ilustrados.com, 2011.

IANNI, O. Estado e Planejamento Econômico no Brasil (1930-1970). $2^{\text {a }}$ ed. Rio de Janeiro: Civilização Brasileira, 1977.

LAVILLE, C. \& DIONNE, J. A construção do Saber. Manual de metodologia de pesquisa em ciências humanas. Porto Alegre: Editora Artmed. Belo Horizonte: Editora UFMG, 1999.

LEME, A. A. Desenvolvimento e sociologia: uma aproximação necessária. Revista Sociedade e Estado, v. 30, n. 2, Brasília, pp. 495527, 2015.

LIAKOPOULOS, M. Análise argumentativa. In: BAUER, B. W. \& GASKELL, G. (Ed.). Pesquisa qualitativa com texto, imagem e som: um manual prático. Petrópolis, RJ: Vozes, 2002, pp. 218-243.

LOPES, H. C., CONCEIÇÃO, O. A. C. \& PEREIRA, A. J. Limites para institucionalização de uma estratégia nacional de desenvolvimento no Brasil. Desenvolvimento em Debate, v. 7, n. 2, pp. 91-111, 2019.

MIRANDA, A. R. La frontera Uruguay-Brasil y el desarrollo local. Nóesis: Revista de Ciencias Sociales y Humanidades, Universidad Autónoma de Ciudad Juárez, Instituto de Ciencias Sociales y Administración, v. 19, n. 37, 2010.

ODDONE, N. \& PRADO, H.S.A. Free Shops en zonas de frontera del Mercosur: oportunidad o desafío para la integración a la luz de la reciente legislación brasileña. Revista Tempo do Mundo, v. 1, pp. 105-121, 2015.
PREFEITURA MUNICIPAL DE JAGUARÃO. Pac Cidades Históricas destina 40 milhões para valorização do patrimônio de Jaguarão, 22/08/2013. Disponível em: https://bit. ly/3yaWLuD. Acesso em: 25 mar. 2016.

PREFEITURA MUNICIPAL DE JAGUARÃO. Público lota Biblioteca para debater a implantação dos free-shops nas cidades brasileiras de fronteira, 01/07/2015. Disponível em https://bit.ly/3xc5yei. Acesso em: 18 jul. 2015.

SANTOS, M. O retorno do território. OSAL: Observatorio Social de América Latina. Ano 6, n. 16. Buenos Aires: CLACSO, 2005.

SCHUMPETER, J. A. A Teoria do Desenvolvimento Econômico: uma investigação sobre lucros, capital, crédito, juro e o ciclo econômico São Paulo: Nova Cultural, 1988.

SENNETT, R. Carne e pedra: O corpo e a cidade na civilização ocidental. $3^{\mathrm{a}}$ ed., Rio de Janeiro: Record, 2003.

SENNETT, R. Boundaries and Borders. In: BURDETT, R., SUDJIC, D. (Org). Living in the Endless City. London: Phaidon Press, 2011, pp. 324-331.

SENNETT, R. The Open City. Lecture transcription of the Understanding Society: Centre for Research in the Arts, Social Sciences \& Humanities, University of Cambridge, 2013.

SILVA, S. P. Avanços e Limites na Implementação de Políticas Públicas Nacionais sob a Abordagem Territorial no Brasil. Instituto de Pesquisa Econômica Aplicada - Texto para discussão. Rio de Janeiro: IPEA, 2013.

SILVA, T. V. \& PRADO, H. S. A. Lojas francas na fronteira: breves apontamentos sobre a Lei $n^{\circ} 12.723 / 2012$. Revista Eletrônica Direito e Política, v. 9, pp. 493-516, 2014.

TEOBALDO, I. N. C. A cidade espetáculo: efeito da globalização. Sociologia: Revista do Departamento de Sociologia da FLUP, V.XX, 2010, pp. 137-148. 
TRIVIÑOS, A. N. S. Introdução à pesquisa em ciências sociais: a pesquisa qualitativa em educação. São Paulo: Atlas, 1987.

VAINER, C. B. Pátria, empresa e mercadoria - Notas sobre a estratégia discursiva do Planejamento Estratégico Urbano. In: ARANTES, O.; VAINER, C.; MARICATO, E. A cidade do pensamento único. Desmanchando consensos. Petrópolis: Editora Vozes, 2000. VITTE, C. C. S. Gestão do desenvolvimento econômico local: algumas considerações. In: Revista Internacional de Desenvolvimento Local, v. 8, n. 13, 2006, pp. 77-87.

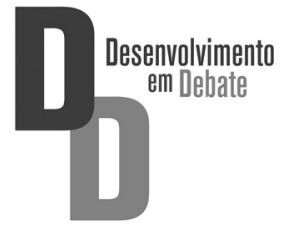

